\title{
Fetal surgery for myelomeningocele is effective: a critical look at the whys
}

\author{
Martin Meuli • Ueli Moehrlen
}

Accepted: 27 May 2014/Published online: 8 June 2014

(C) Springer-Verlag Berlin Heidelberg 2014

\begin{abstract}
Formerly, the disastrous cluster of neurologic deficits and associated neurogenic problems in patients with myelomeningocele (MMC) was generally thought to solely result from the primary malformation, i.e., failure of neurulation. Today, however, there is no doubt that a dimensional additional pathogenic mechanism exists. Most likely, it contributes much more to loss of neurologic function than non-neurulation does. Today, there is a large body of compelling experimental and clinical evidence confirming that the exposed part of the non-neurulated spinal cord is progressively destroyed during gestation, particularly so in the third trimester. These considerations gave rise to the two-hit-pathogenesis of MMC with nonneurulation being the first and consecutive in utero acquired neural tissue destruction being the second hit. This novel pathophysiologic understanding has obviously triggered the question whether the serious and irreversible functional loss caused by the second hit could not be prevented or, at least, significantly alleviated by timely protecting the exposed spinal cord segments, i.e., by early in utero repair of the MMC lesion. Based on this intriguing hypothesis and the above-mentioned data, human fetal surgery for MMC was born in the late nineties of the last century and has made its way to become a novel standard of care, particularly after the so-called "MOMS Trial". This trial, published in the New England Journal of Medicine, has indisputably shown that overall, open prenatal
\end{abstract}

M. Meuli $(\bowtie) \cdot$ U. Moehrlen

Department of Pediatric Surgery, University Children's Hospital

Zurich, Steinwiesstrasse 75, 8032 Zurich, Switzerland

e-mail: martin.meuli@kispi.uzh.ch

M. Meuli · U. Moehrlen

The Zurich Center for Fetal Diagnosis and Therapy,

University of Zurich, Zurich, Switzerland repair is distinctly better than postnatal care alone. Finally, a number of important other topics deserve being mentioned, including the necessity to work on the up till now immature endoscopic fetal repair technique and the need for concentration of these extremely challenging cases to a small number of really qualified fetal surgery centers worldwide. In conclusion, despite the fact that in utero repair of MMC is not a complete cure and not free of risk for both mother and fetus, current data clearly demonstrate that open fetal-maternal surgery is to be recommended as novel standard of care when pregnancy is to be continued and when respective criteria for the intervention before birth are met. Undoubtedly, it is imperative to inform expecting mothers about the option of prenatal surgery once their fetus is diagnosed with open spina bifida.

Keywords Fetal surgery $\cdot$ Myelomeningocele $\cdot$ Spina bifida $\cdot$ Prenatal diagnosis

\section{Introduction}

The first surgeon to ever operate on a human being in utero was Michael R. Harrison from San Francisco, USA, who performed an open vesicostomy in a fetus with posterior urethral valves in 1981 [1].

Even though fetal surgery has made enormous progress over the last 30 years, there are still only few conditions justifying a surgical intervention before birth. The classical indications are open spina bifida (open repair), congenital pulmonary airway malformations (open resection), sacrococcygeal teratomas (open resection), and congenital diaphragmatic hernia (endoscopic tracheal plugging) [2-8].

The goal of this article is to review all pertinent aspects with regard to fetal surgery for spina bifida aperta, or 
myelomeningocele (MMC) which, by far, represents the most frequent and thus also the clinically most relevant indication for prenatal surgery today.

\section{A radical change of paradigm: secondary, i.e., in utero acquired, CNS pathology plays a crucial pathophysiological role}

Until the end of the last century, MMC (spina bifida cystica aperta) and the sister malformation termed myeloschisis (the non-cystic variant) were thought to be the result of non-neurulation, typically occurring at the end of the first gestational month in the lumbosacral area of the spinal cord. Also, the most serious neurological and developmental problems including the rather complex Chiari II malformation, hydrocephalus, paraparesis or paraplegia, neuropathic voiding problems of bladder and rectum, as well as multiple orthopedic pathologies, and also endocrinologic, sexual, intellectual, and psychosocial abnormalities were basically attributed to the primary malformation. Of note, at term, all neurologic deficits are irreversible and there is no real cure for any of the above-mentioned conditions. The patients suffer from a lifelong cluster of handicaps and depend on corrective, rehabilitative, or palliative therapeutic measures.

The first histological descriptions of postnatal MMC lesions showing signs of mechanical trauma, neural tissue degeneration, and massive inflammation were published about 60 years ago by Patten [9] and Cameron [10]. They suggested that this marked spinal cord damage was most likely caused by labor and a harmful passage through the narrow birth canal that crushed and abraded the openly exposed and thus extremely vulnerable neural tissue. Interestingly, there was no explicit mentioning that these apparently late gestational and secondary phenomena could be key factors for the neurological deficit. Also, there was no speculation that during the prenatal development of MMC there might be an early phase of relatively good or even near normal spinal cord function despite partial nonneurulation.

Only when fetal surgery was launched by Harrison [1], a specific understanding was gradually established that congenital malformations do in fact have a natural prenatal history during which dramatic and clinically relevant, mostly negative, processes occur. With regard to open spina bifida, the in utero natural history was studied extensively over the past few decades and convincing experimental as well as clinical evidence led to the "two-hit-pathogenesis" for this devastating malformation. Hence, the first hit is non-neurulation and the second is in utero acquired spinal cord destruction. The thrilling story of how this novel concept was elaborated is narrated below.
The contemporary key figures were Johns Hopkins pathologist Grover M. Hutchins and a number of partner researchers including Heffez, Jordan, Blakemore, and Meuli who analyzed the MMC lesions of a few dozens of human fetuses with spina bifida aperta in detail [11-16]. Taken together, this research line has, for the first time, provided an accurate anatomical description of the typical MMC lesion that is graphically depicted in Fig. 1. Hereby, one observation is of particular clinical relevance. Although the spinal cord tissue within the lesion is always non-neurulated, the characteristic histologic hallmarks of the cord as well as the sensorimotor projections to and from it were present on a regular basis. Furthermore, the exposed neural tissue was histologically intact in early gestation, but showed progressive damage (abrasion, erosion, disruption, hemorrhage, inflammation, degeneration) and finally even disappeared in some specimens completely in late gestation [12, 16]. Since these features were found in all cases alike, it was tenable to derive the "two-hit-pathogenesis" from them with the primary malformation (non-neurulation) representing the first, and in utero acquired damage (trauma, inflammation, degeneration) representing the second hit. This quite revolutionary pathophysiological understanding instantly fuelled the intriguing idea that timely in utero protective coverage of a MMC lesion could stop the otherwise progressing spinal cord destruction and thus salvage neurologic function at birth. Perhaps, following prenatal repair, the power of fetal wound healing and a good deal of neural plasticity could eventually lead to recuperation of function previously lost.

There is compelling experimental evidence, in particular the one generated by Micheida (monkey) [17], Heffez (rat and pig) [13, 14], Jennings (rabbit) [18] and Meuli (sheep) [19-21] to demonstrate that surgically created lesions mimicking as closely as possible the human open spina bifida lesion in experimental fetuses led to characteristic MMC lesions and loss of function at birth. The two studies mimicking best the natural in utero course of human MMC and also the marked functional benefit induced by in utero repair of such lesions are the ones published by Meuli/Adzick in Nature Medicine [19] and by Stiefel/Meuli in The Journal of Neurosurgery [22]. The Nature Medicine article essentially demonstrates in a fetal sheep model that a surgically created human-like spina bifida defect with exposure of the normal spinal cord to the amniotic fluid, performed at midgestation, developed into an almost classical human-like cystic MMC lesion at birth. And, even more importantly, the newborn lambs were paraplegic and incontinent. These dynamics prove that direct and prolonged exposure of normal spinal cord tissue to the amniotic cavity leads to dramatic loss of 


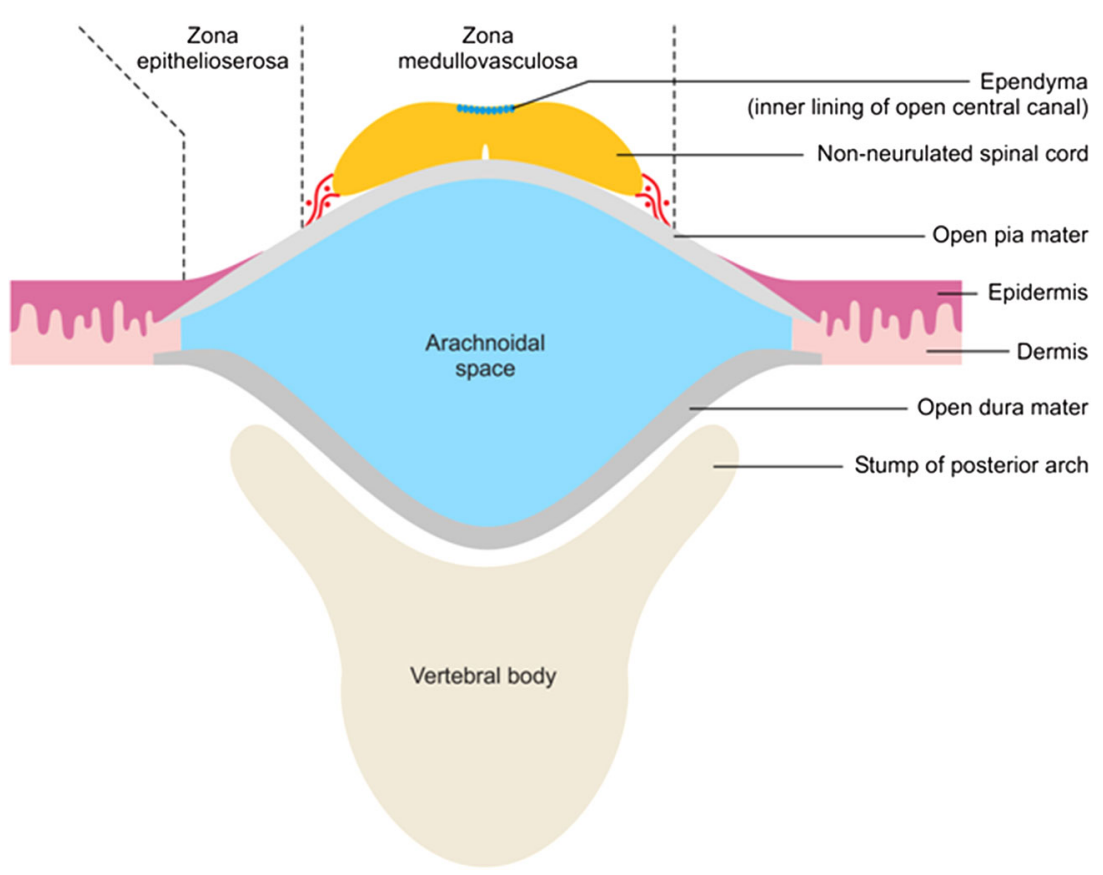

Fig. 1 Graphical cross section through the center of the classical cystic human MMC lesion: the non-neurulated spinal cord resides on top of a cystic formation that is dorsally formed by open pia and ventrally by open dura. The neural tissue is directly exposed to the amniotic fluid during gestation, or to air post birth. The abnormally shaped arachnoid space contains cerebrospinal fluid. The pia mater merges bilaterally into the epidermis and superficial dermis, the dura mater merges into the deep dermis of the normal skin that surrounds the lesion. In case of the so-called myeloschisis, the arachnoidal space is collapsed, and the non-neurulated spinal cord rests in the gutter formed by the vertebral body and the remnants of the vertebral arches. $\left({ }^{\odot}\right.$ Georg Thieme Verlag KG) function. The same article also reports on successful in utero repair of developing "mini"-MMC. Fetuses in which a midgestational MMC was created and then repaired in utero using a distally pedicled latissimus dorsi flap [23] 4 weeks thereafter were neurologically normal at birth. These results prove that timely in utero coverage of exposed spinal cord tissue is protective and spares function [19]. The Journal of Neurosurgery article delivers a sort of ultimate proof for the correctness of the two-hit-pathogenesis by looking at the natural in utero and postnatal course in a genetic mouse model of MMC. Early gestational MMC fetuses demonstrated sensorimotor function that was identical with that of healthy control fetuses, and, anatomically, they showed normal sensory and motor projections to and from the non-neurulated but otherwise intact spinal cord. Neonatal pups, however, were paralyzed and histologically, there were no or only minimal residues of the formerly exposed neural tissue [22]. This "experiment of nature" confirms that spinal cord function is present in early gestation and is progressively diminished during later stages of gestation until an almost complete and irreversible loss at birth. A number of experimental studies were carried out and basically corroborated the conclusions drawn from the above studies [24-29]. An important piece of understanding was added by Bouchard and Paek who independently produced evidence (using the fetal sheep model originally described by Meuli et al.) that a kind of "Chiari-malformation" with hindbrain herniation and hydrocephalus formation can be induced when a cerebrospinal fluid leak is created within the lumbar MMC lesion and that this process is reversible upon in utero coverage of the lesion [30, 31].

Taken together, the above-quoted evidence has paved the way for fetal surgery to be commenced in human fetuses suffering from this ruinous malformation.

\section{Diagnostic workup and prenatal counseling}

An open spina bifida is mainly detected by ultrasound first (it can be seen as early as about 16 weeks of gestation) and then confirmed by a fetal-maternal MRI. For a fetus and his mother to qualify for maternal-fetal surgery, the mother must be healthy (there is a long list of exclusion criteria!), the fetus must not suffer from other pathologies than the MMC complex, and the intervention must be performed between 20 and 26 weeks of gestation. Of course, a written 


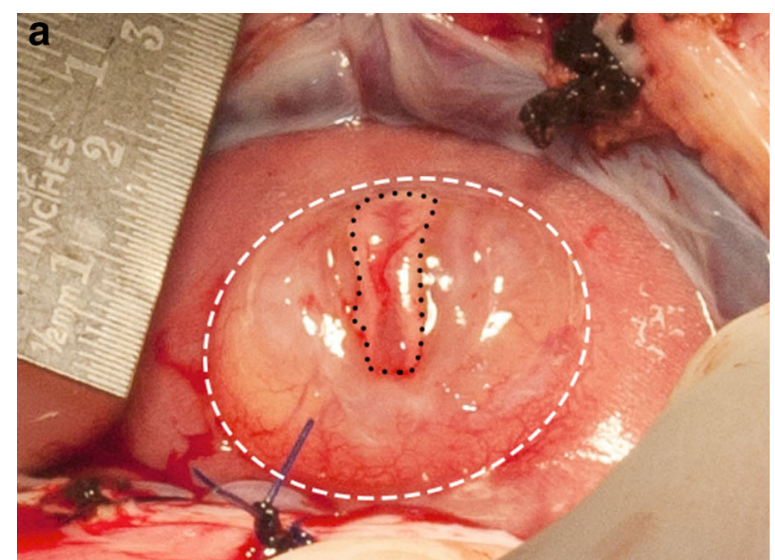

Fig. 2 Open fetal surgery: a the cystic sac (zona epithelioserosa; between dotted lines) is being resected. In the center of the picture lies the openly exposed, non-neurulated, but macroscopically undamaged

informed consent must be obtained following a nondirective prenatal counseling.

\section{The first studies of human fetal surgery for MMC produce encouraging results and set the stage for the MOMS Trial (Management of Myelomeningocele Study)}

The pre-MOMS era was essentially coined by the work of the three American centers who later joined forces to carry out the MOMS Trial. In 1997, Bruner from Vanderbilt University reported on the very first case of a (non successful) endoscopic human fetal MMC repair [32]. In 1998, Adzick, from the Children's Hospital of Philadelphia (CHOP), performed the first (successful) open repair (Fig. 2) [33]. A year later, Bruner and Sutton (CHOP) published sister papers in the same JAMA issue reporting that fetal $\mathrm{MMC}$ repair reversed hindbrain herniation (Fig. 3) in almost all fetuses and thereby reduced the need for shunt placement by about $50 \%$ [34, 35]. The Philadelphia group also produced a remarkable sequence of follow-up studies essentially confirming that hindbrain herniation is reversible and that the shunt rate drops dramatically [36, 37]. Moreover, the CHOP cohort exhibited a favorable evolution with regard to head size [38], brainstem function [39], motor function of the legs [40], and several neurodevelopmental parameters [41, 42]. On the negative side of the spectrum, some patients had neurological worsening due to retethering of the spinal cord at the repair site [43]. The Vanderbuilt group studied bladder and bowel function 7-10 years after in utero repair and did not find significant differences from patients with postnatal care [44]. Interestingly, there is a

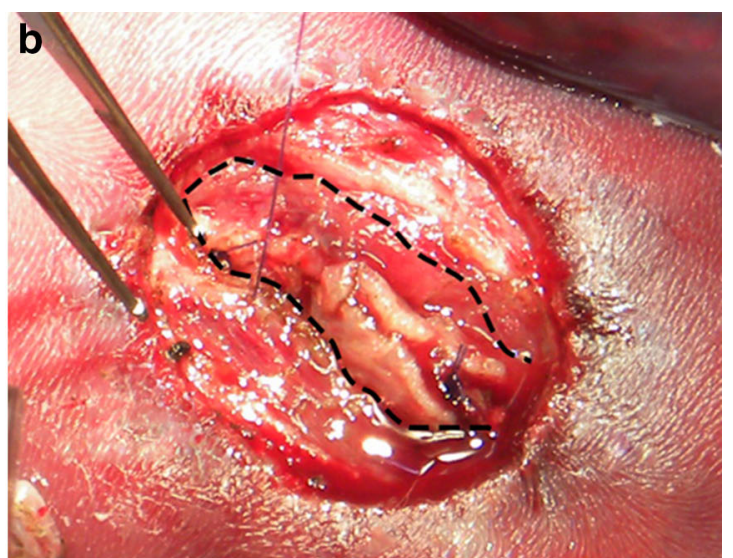

spinal cord. b Bilateral myofascial (dotted line) flaps are being sewn over the cord (this is one of our own cases)

study showing a global defect in smooth and skeletal muscle as well as nerve density in the lower genitourinary and gastrointestinal tract of male human fetuses with MMC at 20 weeks of gestation [45]. A study by the Vanderbuilt group revealed that fetal repair beyond the 26th gestational week is not as effective anymore (Fig. 4). This is one reason why the window of opportunity for fetal repair, i.e., from 20 to 26 gestational weeks, closes at this timepoint [46]. Importantly, the CHOP group has shown that women do not experience a loss of reproductive capacity due to maternal-fetal surgery nor do they have higher hysterotomy risks than those present after conventional C-sections [47, 48]. In summary, the ensemble of all clinical data fostered the conception of what finally turned out to be the most influential milestone study ever conducted in the history of fetal surgery: The MOMS Trial, a prospective, randomized, multicenter clinical trial to compare 100 fetal with 100 postnatal MMC repairs.

\section{The MOMS trial makes open fetal surgery a novel treatment standard}

The trial started in 2003 and was prematurely stopped by the data and safety monitoring committee in 2010 after inclusion of 183 of the planned 200 eligible women. Because of significantly better results in the fetal therapy group, further randomization was considered unjustifiable and unethical. The key findings with regard to the primary and some of the most relevant secondary outcomes are listed and commented on below.

The prenatal surgery group compared favorably with the postnatal surgery group in terms of both primary outcomes, 
Fig. 3 a Before surgery: small posterior fossa and marked hindbrain herniation into the proximal cervical spine (white arrow). The large cystic MMC is clearly discernible (asterisk). b Fetal MRI 4 weeks after fetal surgery. Hindbrain herniation is already completely resolved. c Neonatal MRI at 10 days of life: There is no hindbrain herniation and the medulla oblongata can be seen in projection on the foramen occipitale magnum (white arrow) (this is one of our own cases)
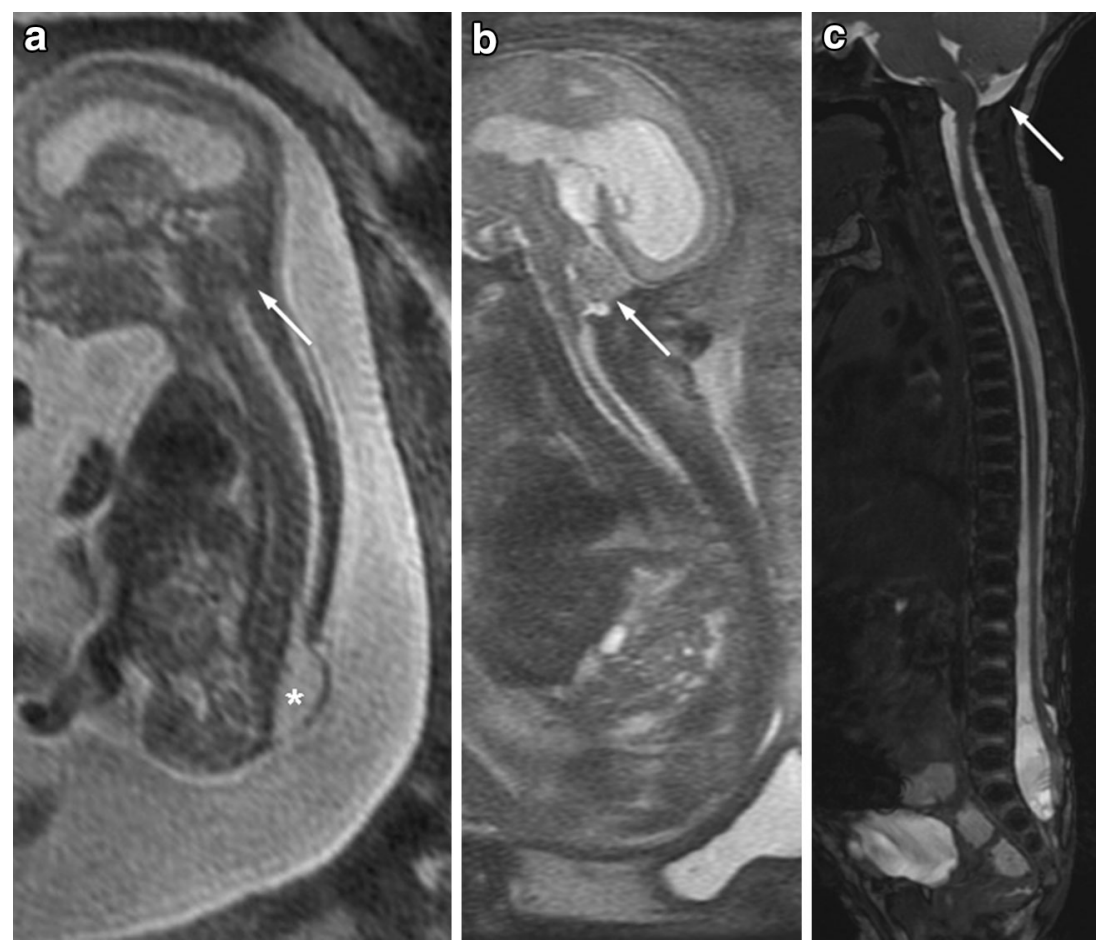

Fig. 4 Three typical aspects (own cases) of repair sites on the first day of life. A perfectly healed skin, no cerebrospinal fluid leak, and a suture that is still in place is what we observe on a regular basis
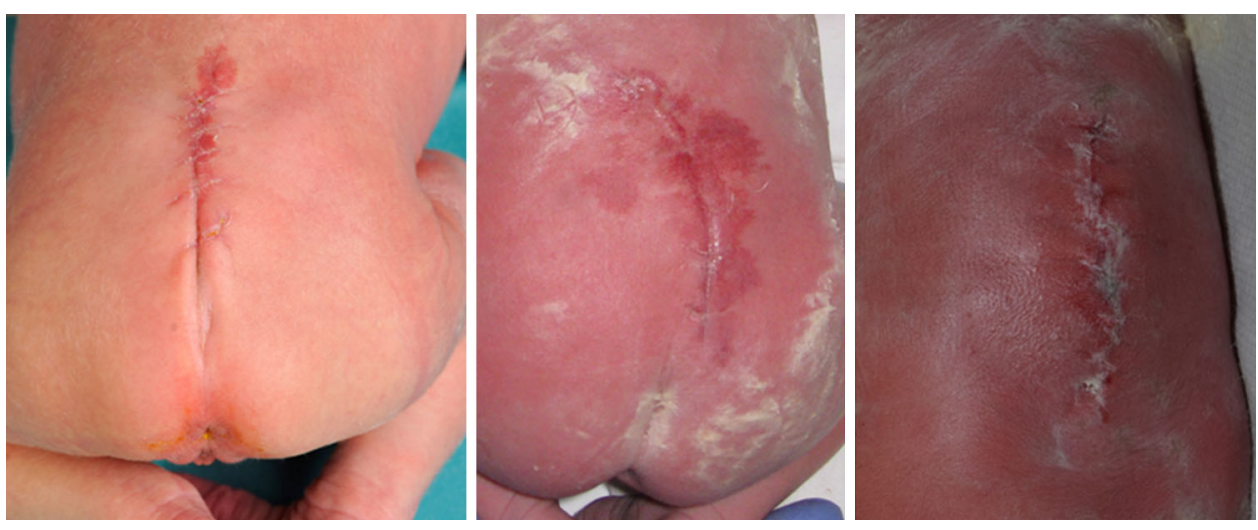

i.e., fetal or neonatal death and shunt placement at 12 months of age, as well as mental development and motor function at 30 months of age (highly significant statistics!).

Also, the prenatal surgery group showed significantly better secondary outcomes with regard to hindbrain herniation, lower extremity motor function, and chances of independent walking.

However, the risks of spontaneous rupture of membranes, persistent oligohydramnios, spontaneous labor, and preterm delivery were significantly higher in the prenatal than in the postnatal surgery group.

Maternal safety was preserved throughout the trial. Of note, $25 \%$ of women with fetal surgery demonstrated uterine wall thinning in the hysterotomy area, $10 \%$ had dehiscences. Yet, a uterine rupture did not occur.
Considering all data generated by the MOMS Trial and after judicious weighing of benefits against risks, the following conclusions appear correct: although open maternal-fetal surgery for MMC is not completely curative and not free of risks, it definitely yields the best overall results achievable today. Therefore, it represents a novel standard of care that must be taken into consideration when a fetus is diagnosed with this devastating malformation.

\section{Percutaneous, endoscopic fetal MMC repair: a problematic approach}

Fetal endoscopic interventions have already conquered a certain position in the field of prenatal medicine, for instance with regard to laser therapy for twin-twin transfusion syndrome [49] or tracheal plugging in severe cases 
of congenital diaphragmatic hernia [50]. Of note, these procedures do not involve formal surgical steps like cutting, preparing, resecting, and suturing of tissues, or meticulous hemostasis, all of which are indispensable for a neurosurgically correct MMC repair.

In theory, a minimally invasive repair variant looks attractive, in particular if the well-documented benefits associated with postnatal endoscopic operations would also be present in the prenatal setting.

Until present, three centers have reported on their results with endoscopic surgery (Bruner, Nashville, USA [32, 51, 52]; Farmer, San Francisco, USA [53]; Kohl, Giessen-Marburg, formerly Bonn, Germany [54-56]). In the upshot, some of these patients might have drawn benefit from the fetal endoscopic intervention, yet patient numbers are two small $[32,51,53]$, or, data are inconsistent $[54,55,57,58]$ so that a clean picture regarding positive effects is difficult to obtain. On the other hand, these reports provided details on staggering rates of serious complications, including intraoperative fetal death, massive trocar site hemorrhage with termination of a not completed intervention, partial or failed patch coverage of the lesion so that postnatal repair was mandatory, technical issues forcing conversion to open surgery, extremely long operations times, oligohydramnios due to port site leakage, premature rupture of amniotic membranes, chorioamnionitis, and extreme prematurity (e.g., 28 weeks mean age at delivery!) [32, 53, 55, 58, 59]. Based on these grim experiences, the two US centers understandably abandoned the endoscopic approach, while the center in Giessen-Marburg continues the program.

Definitely, the multiple port sites represent the main problem on the maternal side: ports are inserted percutaneously into the amniotic cavity (no direct vision!), are moved around over long hours in an anatomically frail environment where chorionic and amniotic membranes are very loosely affixed, thus they are prone to tearing and bleeding. Finally, these ports are pulled out, again without direct vision and, crucially, with absolute no means to control and seal said membranes and no ways to reliably stop eventual bleeding or amniotic fluid leakage. Thus, the stage is set for uncontrollable hemorrhage as well as uncontrollable rupture and separation of membranes. Consequently, risks are high for amniotic fluid leak, oligohydramnios, uterine wall hematoma, chorioamnionitis, premature labor, and premature birth. All of these dangerous complications may turn out fatal. Of note, the stapler employed for open hysterotomy warrants, on a very reliable basis, membrane and muscle layer sealing throughout the operation.

The main problem on the fetal side is that the endoscopic "repair" mainly consists of a simple patch application over the lesion. Although patch coverage may provide a certain protection of the neural tissue, it does by no means come close to the correct and relatively complex neurosurgical reconstruction. The latter mandates a formal resection of the zona epithelioserosa, untethering of the filum terminale, pia mater closure and neural placode tubularization, watertight dura mater closure, reinforcement of that area with paraspinal (myo) fascial flaps, and, finally, skin closure. Of note, the cited method is applied successfully for open fetal repair as well!

Undoubtedly, there is ongoing and harsh controversy over the above-raised critical issues, exemplified by a published statement of David Shurtleff, one of the most renowned spina bifida experts worldwide. In a comment to a recent article by Verbeek et al. reporting on the outcome of 13 endoscopically treated patients of the Marburg-Giessen group, he wrote: "The extremely high complication rates for mother and infant in this study and the principle of primum non nocere indicate that at this time it is unethical to pursue intrauterine endoscopic myelomeningocele repair

Table 1 Recommendation for centers offering fetal surgery for MMC

\footnotetext{
1.Experienced fetal care team consisting of:

Functional team, experienced in collaborative patient care with a designated leader

Care coordinator

Fetal echocardiographer

Fetal surgeon with experience performing hysterotomy and closure

Genetic counselor

Magnetic resonance imaging equipment and expertise to perform and interpret fetal cases

Maternal-fetal medicine specialist

Neonatologist

Obstetric anesthesiologist

Pediatric anesthesiologist

Pediatric neurosurgeon

Social worker

Ultrasound equipment and expertise to perform and interpret fetal cases

2.Multidisciplinary spina bifida program

3.Level IIIC neonatal intensive care unit

4.Labor and delivery unit capable of caring for perioperative complications and obstetric emergencies with around the clock availability of maternal-fetal medicine (MFM) specialists/ obstetricians skilled in managing delivery of patients with a recent hysterotomy

5.Institutional review board

6.Ethics committee

7.Maternal/fetal advocate to ensure that counseling is nondirective

8.Institutional commitment to track long-term pediatric neurodevelopment outcomes
} 
in humans until the procedure has been perfected in animals" [60].

In terms of a general consideration, it appears logical that any alternative approach or program must deliver similar or better results than the evidence-based benchmark of the MOMS Trial to be medically and ethically justifiable.

\section{The post-MOMS era deserves pondered and sensible reflection}

Landmark publications like the MOMS Trial in "The New England Journal of Medicine" tend to produce a hype. An advantage may be that the innovation rapidly gains broad perception, acceptance and, in the best case scenario, a successful global spawn. A downside may be that bad results produced by adventurous yet unqualified pseudoexperts jeopardise the newborn novelty.

The authors of this review applaud the fact that in February 2014, a position paper appeared in the American Journal of Obstetrics and Gynecology, authored by a newly composed expert group from all involved disciplines, i.e., the "MMC Maternal-Fetal Management Task Force" [61]. This article outlines a framework of minimal prerequisites (Table 1) that must be fulfilled for a center to offer prenatal treatment for MMC. Even though such an initiative does, needless to say, not have legal power, it may develop the power of a generally accepted and publicly known (Internet!) codex of conduct risky not to comply with. The worldwide community of experts in the field of fetal diagnosis and therapy has, now!, the unique chance to set forth rigorous rules and regulations to define and certify centers allowed to offer fetal surgery for MMC.

\section{The world map today}

In light of the above allocation considerations, it is mandatory to have a look at the status quo. To the best of our knowledge, a total of 7 centers are offering fetal surgery for spina bifida in the US: Apart from the three MOMS Trial Centers, there is Cincinnati, Houston (two programs, competing across the street, sic!) [62], and Denver. In South America, there is a center in Sao Paolo, Brasil, with remarkable experience and several clinical publications [63-65]. All other programs seem to be located in Europe. The ones who have reported on their results in peerreviewed articles are in Katowice, Poland [66] and Zurich, Switzerland [67-69]. Our program was started in December 2010 when the MOMS Trial was stopped. We have treated thirteen cases so far and, overall, our preliminary results are in line with those of the MOMS Trial (manuscript in preparation). Finally, there is a program in Barcelona, Spain, and one in Leuven, Belgium (no clinical publications).

\section{Future homework and responsibilities}

There are a number of issues that must be addressed by those performing fetal surgery for MMC. Clearly, longterm follow-up studies are a must to check whether results are durable. The as of yet immature endoscopic approach must be freed from its currently prohibitive quandaries. Engineering fetal dura mater and fetal skin equivalents could facilitate the operation and improve results. Other tissue engineering strategies like the ones suggested by Flake [70, 71] or molecular biology-based approaches might eventually originate entirely new, non-surgical therapies.

After all, and again, these rare, complex, and extremely challenging cases must be treated in a few really qualified high-volume centers. Undeniably, case load dilution jeopardises outcome and is therefore against the best interest of the courageous expectant mother and her unborn child.

\section{Conclusions}

Although the MOMS Trial has generated an unparalleled quality of evidence in favor of open fetal surgery, there are three relevant reservations: maternal-fetal surgery is not a cure, it is not devoid of risks for both mother and fetus, and there is not yet proof of durable, ideally life-long, benefit. Nevertheless, prenatal repair is the novel standard of care and must be offered to those women who are eligible and determined to offer their yet to be born child the best chance there is today.

\section{References}

1. Harrison MR, Golbus MS, Filly RA, Callen PW, Katz M, De Lorimier AA, Rosen M, Jonsen AR (1982) Fetal surgery for congenital hydronephrosis. N Engl J Med 306:591-593

2. Adzick NS (2010) Open fetal surgery for life-threatening fetal anomalies Semin. Fetal Neonatal Med 15:1-8

3. Adzick NS, Thom EA, Spong CY, Brock JW III, Burrows PK, Johnson MP, Howell LJ, Farrell JA, Dabrowiak ME, Sutton LN, Gupta N, Tulipan NB, D'Alton ME, Farmer DL (2011) A randomized trial of prenatal versus postnatal repair of myelomeningocele. N Engl J Med 364:993-1004

4. Hedrick HL, Flake AW, Crombleholme TM, Howell LJ, Johnson MP, Wilson RD, Adzick NS (2004) Sacrococcygeal teratoma: prenatal assessment, fetal intervention, and outcome. J Pediatr Surg 39:430-438 
5. Hirose S, Farmer DL (2003) Fetal surgery for sacrococcygeal teratoma. Clin Perinatol 30:493-506

6. Jani JC, Nicolaides KH, Gratacos E, Valencia CM, Done E, Martinez JM, Gucciardo L, Cruz R, Deprest JA (2009) Severe diaphragmatic hernia treated by fetal endoscopic tracheal occlusion. Ultrasound Obstet Gynecol 34:304-310

7. Kitano Y, Flake AW, Crombleholme TM, Johnson MP, Adzick NS (1999) Open fetal surgery for life-threatening fetal malformations. Semin Perinatol 23:448-461

8. Vrecenak JD, Flake AW (2013) Fetal surgical intervention: progress and perspectives. Pediatr Surg Int 29:407-417

9. Patten BM (1953) Embryological stages in the establishing of myeloschisis with spina bifida. Am J Anat 93:365-395

10. Cameron AH (1956) The spinal cord lesion in spina bifida cystica. Lancet 271:171-174

11. Hutchins GM, McGowan KD, Blakemore KJ (1992) Spinal dysraphia: not a neural tube defect? Am J Hum Genet 51:A319

12. Hutchins GM, Meuli M, Meuli-Simmen C, Jordan MA, Heffez DS, Blakemore KJ (1996) Acquired spinal cord injury in human fetuses with myelomeningocele. Pediatr Pathol Lab Med 16:701-712

13. Heffez DS, Aryanpur J, Hutchins GM, Freeman JM (1990) The paralysis associated with myelomeningocele: clinical and experimental data implicating a preventable spinal cord injury. Neurosurgery 26:987-992

14. Heffez DS, Aryanpur J, Rotellini NA, Hutchins GM, Freeman JM (1993) Intrauterine repair of experimental surgically created dysraphism. Neurosurgery 32:1005-1010

15. Jordan MA, Heffez DS, Hutchins GM (1991) The relationships of the spinal cord and meninges in meningocele, meningomyelocele and iniencephaly. Teratology 43:472

16. Meuli M, Meuli-Simmen C, Hutchins GM, Seller MJ, Harrison MR, Adzick NS (1997) The spinal cord lesion in human fetuses with myelomeningocele: implications for fetal surgery. J Pediatr Surg 32:448-452

17. Michejda M (1984) Intrauterine treatment of spina bifida: primate model. Z Kinderchir 39:259-261

18. Housley HT, Graf JL, Lipshultz GS, Calvano CJ, Harrison MR, Farmer DL, Jennings RW (2000) Creation of myelomeningocele in the fetal rabbit. Fetal Diagn Ther 15:275-279

19. Meuli M, Meuli-Simmen C, Hutchins GM, Yingling CD, Hoffman KM, Harrison MR, Adzick NS (1995) In utero surgery rescues neurological function at birth in sheep with spina bifida. Nat Med 1:342-347

20. Meuli M, Meuli-Simmen C, Yingling CD, Hutchins GM, Hoffman KM, Harrison MR, Adzick NS (1995) Creation of myelomeningocele in utero: a model of functional damage from spinal cord exposure in fetal sheep. J Pediatr Surg 30:1028-1032

21. Meuli M, Meuli-Simmen C, Yingling CD, Hutchins GM, Timmel GB, Harrison MR, Adzick NS (1996) In utero repair of experimental myelomeningocele saves neurological function at birth. J Pediatr Surg 31:397-402

22. Stiefel D, Copp AJ, Meuli M (2007) Fetal spina bifida in a mouse model: loss of neural function in utero. J Neurosurg 106:213-221

23. Meuli-Simmen C, Meuli M, Hutchins GM, Harrison MR, Buncke HJ, Sullivan KM, Adzick NS (1995) Fetal reconstructive surgery: experimental use of the latissimus dorsi flap to correct myelomeningocele in utero. Plast Reconstr Surg 96:1007-1011

24. Danzer E, Kiddoo DA, Redden RA, Robinson L, Radu A, Zderic SA, Doolin EJ, Adzick NS, Flake AW (2007) Structural and functional characterization of bladder smooth muscle in fetal rats with retinoic acid-induced myelomeningocele. Am J Physiol Renal Physiol 292:F197-F206

25. Danzer E, Radu A, Robinson LE, Volpe MV, Adzick NS, Flake AW (2008) Morphologic analysis of the neuromuscular development of the anorectal unit in fetal rats with retinoic acid induced myelomeningocele. Neurosci Lett 430:157-162

26. Danzer E, Zhang L, Radu A, Bebbington MW, Liechty KW, Adzick NS, Flake AW (2011) Amniotic fluid levels of glial fibrillary acidic protein in fetal rats with retinoic acid induced myelomeningocele: a potential marker for spinal cord injury. Am J Obstet Gynecol 204:178

27. Encinas JL, Garcia-Cabezas MA, Barkovich J, Fontecha CG, Peiro JL, Soto GM, Borrell V, Reillo I, Lopez-Santamaria M, Tovar JA, Farmer DL (2011) Maldevelopment of the cerebral cortex in the surgically induced model of myelomeningocele: implications for fetal neurosurgery. $\mathbf{J}$ Pediatr Surg 46:713-722

28. Stiefel D, Meuli M (2007) Scanning electron microscopy of fetal murine myelomeningocele reveals growth and development of the spinal cord in early gestation and neural tissue destruction around birth. J Pediatr Surg 42:1561-1565

29. Shen J, Zhou G, Chen H, Bi Y (2013) Morphology of nervous lesion in the spinal cord and bladder of fetal rats with myelomeningocele at different gestational age. J Pediatr Surg 48:2446-2452

30. Bouchard S, Davey MG, Rintoul NE, Walsh DS, Rorke LB, Adzick NS (2003) Correction of hindbrain herniation and anatomy of the vermis after in utero repair of myelomeningocele in sheep. J Pediatr Surg 38:451-458

31. Paek BW, Farmer DL, Wilkinson CC, Albanese CT, Peacock W, Harrison MR, Jennings RW (2000) Hindbrain herniation develops in surgically created myelomeningocele but is absent after repair in fetal lambs. Am J Obstet Gynecol 183:1119-1123

32. Bruner JP, Tulipan NE, Richards WO (1997) Endoscopic coverage of fetal open myelomeningocele in utero. Am J Obstet Gynecol 176:256-257

33. Adzick NS, Sutton LN, Crombleholme TM, Flake AW (1998) Successful fetal surgery for spina bifida. Lancet 352:1675-1676

34. Bruner JP, Tulipan N, Paschall RL, Boehm FH, Walsh WF, Silva SR, Hernanz-Schulman M, Lowe LH, Reed GW (1999) Fetal surgery for myelomeningocele and the incidence of shuntdependent hydrocephalus. JAMA 282:1819-1825

35. Sutton LN, Adzick NS, Bilaniuk LT, Johnson MP, Crombleholme TM, Flake AW (1999) Improvement in hindbrain herniation demonstrated by serial fetal magnetic resonance imaging following fetal surgery for myelomeningocele. JAMA 282:1826-1831

36. Johnson MP, Sutton LN, Rintoul N, Crombleholme TM, Flake AW, Howell LJ, Hedrick HL, Wilson RD, Adzick NS (2003) Fetal myelomeningocele repair: short-term clinical outcomes. Am J Obstet Gynecol 189:482-487

37. Rintoul NE, Sutton LN, Hubbard AM, Cohen B, Melchionni J, Pasquariello PS, Adzick NS (2002) A new look at myelomeningoceles: functional level, vertebral level, shunting, and the implications for fetal intervention. Pediatrics 109:409-413

38. Danzer E, Johnson MP, Bebbington M, Simon EM, Wilson RD, Bilaniuk LT, Sutton LN, Adzick NS (2007) Fetal head biometry assessed by fetal magnetic resonance imaging following in utero myelomeningocele repair. Fetal Diagn Ther 22:1-6

39. Danzer E, Finkel RS, Rintoul NE, Bebbington MW, Schwartz ES, Zarnow DM, Adzick NS, Johnson MP (2008) Reversal of hindbrain herniation after maternal-fetal surgery for myelomeningocele subsequently impacts on brain stem function. Neuropediatrics 39:359-362

40. Danzer E, Gerdes M, Bebbington MW, Sutton LN, Melchionni J, Adzick NS, Wilson RD, Johnson MP (2009) Lower extremity neuromotor function and short-term ambulatory potential following in utero myelomeningocele surgery. Fetal Diagn Ther $25: 47-53$ 
41. Danzer E, Gerdes M, Bebbington MW, Zarnow DM, Adzick NS, Johnson MP (2010) Preschool neurodevelopmental outcome of children following fetal myelomeningocele closure. Am J Obstet Gynecol 202:450-459

42. Johnson MP, Gerdes M, Rintoul N, Pasquariello P, Melchionni J, Sutton LN, Adzick NS (2006) Maternal-fetal surgery for myelomeningocele: neurodevelopmental outcomes at 2 years of age. Am J Obstet Gynecol 194:1145-1150

43. Danzer E, Adzick NS, Rintoul NE, Zarnow DM, Schwartz ES, Melchionni J, Ernst LM, Flake AW, Sutton LN, Johnson MP (2008) Intradural inclusion cysts following in utero closure of myelomeningocele: clinical implications and follow-up findings. J Neurosurg Pediatr 2:406-413

44. Clayton DB, Tanaka ST, Trusler L, Thomas JC, Pope JC, Adams MC, Brock JW III (2011) Long-term urological impact of fetal myelomeningocele closure. J Urol 186:1581-1585

45. Shapiro E, Seller MJ, Lepor H, Kalousek DK, Hutchins GM, Perlman EJ, Meuli M (1998) Altered smooth muscle development and innervation in the lower genitourinary and gastrointestinal tract of the male human fetus with myelomeningocele. J Urol 160:1047-1053

46. Tubbs RS, Chambers MR, Smyth MD, Bartolucci AA, Bruner JP, Tulipan N, Oakes WJ (2003) Late gestational intrauterine myelomeningocele repair does not improve lower extremity function. Pediatr Neurosurg 38:128-132

47. Wilson RD, Johnson MP, Flake AW, Crombleholme TM, Hedrick HL, Wilson J, Adzick NS (2004) Reproductive outcomes after pregnancy complicated by maternal-fetal surgery. Am J Obstet Gynecol 191:1430-1436

48. Wilson RD, Lemerand K, Johnson MP, Flake AW, Bebbington M, Hedrick HL, Adzick NS (2010) Reproductive outcomes in subsequent pregnancies after a pregnancy complicated by open maternal-fetal surgery (1996-2007). Am J Obstet Gynecol 203:209

49. Roberts D, Neilson JP, Kilby MD, Gates S (2014) Interventions for the treatment of twin-twin transfusion syndrome. Cochrane Database Syst Rev 1:CD002073

50. Cannie MM, Jani JC, De Keyzer F, Allegaert K, Dymarkowski S, Deprest J (2009) Evidence and patterns in lung response after fetal tracheal occlusion: clinical controlled study. Radiology 252:526-533

51. Bruner JP, Richards WO, Tulipan NB, Arney TL (1999) Endoscopic coverage of fetal myelomeningocele in utero. Am J Obstet Gynecol 180:153-158

52. Bruner JP, Tulipan NB, Richards WO, Walsh WF, Boehm FH, Vrabcak EK (2000) In utero repair of myelomeningocele: a comparison of endoscopy and hysterotomy. Fetal Diagn Ther 15:83-88

53. Farmer DL, von Koch CS, Peacock WJ, Danielpour M, Gupta N, Lee H, Harrison MR (2003) In utero repair of myelomeningocele: experimental pathophysiology, initial clinical experience, and outcomes. Arch Surg 138:872-878

54. Degenhardt J, Schurg R, Winarno A, Oehmke F, Khaleeva A, Kawecki A, Enzensberger C, Tinneberg HR, Faas D, Ehrhardt H, Axt-Fliedner R, Kohl T (2014) Percutaneous minimally-invasive fetoscopic surgery for spina bifida aperta. Part II Maternal management and outcome. Ultrasound Obstet, Gynecol

55. Kohl T, Gembruch U (2008) Current status and prospects of fetoscopic surgery for spina bifida in human fetuses. Response to Fichter et al.: Fetal spina bifida repair-current trends and prospects of intrauterine neurosurgery (Fetal Diagn Ther 2008;23:271-286). Fetal Diagn Ther 24:318-320

56. Kohl T, Tchatcheva K, Weinbach J, Hering R, Kozlowski P, Stressig R, Gembruch U (2010) Partial amniotic carbon dioxide insufflation (PACI) during minimally invasive fetoscopic surgery: early clinical experience in humans. Surg Endosc $24: 432-444$
57. Kohl T, Tchatcheva K, Merz W, Wartenberg HC, Heep A, Muller A, Franz A, Stressig R, Willinek W, Gembruch U (2009) Percutaneous fetoscopic patch closure of human spina bifida aperta: advances in fetal surgical techniques may obviate the need for early postnatal neurosurgical intervention. Surg Endosc 23:890-895

58. Verbeek RJ, Heep A, Maurits NM, Cremer R, Hoving EW, Brouwer OF, van der Hoeven JH, Sival DA (2012) Fetal endoscopic myelomeningocele closure preserves segmental neurological function. Dev Med Child Neurol 54:15-22

59. Verbeek RJ, Heep A, Maurits NM (2010) Does fetal endoscopic closure of the myelomeningocele prevent loss of neurologic function in spina bifida aperta? Cereb Fluid Res 7:1-2

60. Shurtleff D (2012) Fetal endoscopic myelomeningocele repair. Dev Med Child Neurol 54:4-5

61. Cohen AR, Couto J, Cummings JJ, Johnson A, Joseph G, Kaufman BA, Litman RS, Menard MK, Moldenhauer JS, Pringle KC, Schwartz MZ, Walker WO Jr, Warf BC, Wax JR (2014) Position statement on fetal myelomeningocele repair. Am J Obstet Gynecol 210:107-111

62. Kahn L, Mbabuike N, Valle-Giler EP, Garces J, Moore RC, Hilaire HS, Bui CJ (2014) Fetal surgery: the ochsner experience with in utero spina bifida repair. Ochsner. J. 14:112-118

63. Hisaba WJ, Cavalheiro S, Almodim CG, Borges CP, de Faria TC, Araujo JE, Nardozza LM, Moron AF (2012) Intrauterine myelomeningocele repair postnatal results and follow-up at 3.5 years of age-initial experience from a single reference service in Brazil. Childs Nerv Syst 28:461-467

64. Macedo A Jr, Leal M, Rondon A, Ortiz V, Moron AF, Cavalheiro $S$ (2014) Urological evaluation of patients that had undergone in utero myelomeningocele closure: a prospective assessment at first presentation and early follow-up. Do their bladder benefit from it? Neurourol Urodyn [Epub ahead of print]

65. Faria TC, Cavalheiro S, Hisaba WJ, Moron AF, Torloni MR, Oliveira AL, Borges CP (2013) Improvement of motor function and decreased need for postnatal shunting in children who had undergone intrauterine myelomeningocele repair. Arq Neuropsiquiatr 71:604-608

66. Zamlyniski J, Olejek A, Bohosiewicz J, Bodzek P, Manka G, Grettka K, Paliga M, Gajewska A (2007) Perinatal results of intrauterine open fetal surgery of fetuses diagnosed with myelomeningocoele-the clinical report of ten cases. Ginekol Pol 78:647-651

67. Meuli M, Moehrlen U, Flake A, Ochsenbein N, Huesler M, Biro P, Scheer I, Tharakan S, Durig P, Zimmermann R (2012) Fetal surgery in Zurich: key features of our first open in utero repair of myelomeningocele. Eur J Pediatr Surg 23(6):494-498

68. Meuli M, Meuli-Simmen C, Flake AW, Zimmermann R, Ochsenbein N, Scheer I, Mazzone L, Moehrlen U (2013) Premiere use of Integra artificial skin to close an extensive fetal skin defect during open in utero repair of myelomeningocele. Pediatr Surg Int 29(12):1321-1326

69. Osinga R, Mazzone L, Meuli M, Meuli-Simmen C, Von Campe A (2014) Assessment of long-term donor site morbidity after harvesting the latissimus dorsi flap for neonatal myelomeningocele repair. J Plast Reconstruct Aesth Surg (in press)

70. Watanabe M, Jo J, Radu A, Kaneko M, Tabata Y, Flake AW (2010) A tissue engineering approach for prenatal closure of myelomeningocele with gelatin sponges incorporating basic fibroblast growth factor. Tissue Eng Part A 16:1645-1655

71. Watanabe M, Li H, Roybal J, Santore M, Radu A, Jo J, Kaneko M, Tabata Y, Flake A (2011) A tissue engineering approach for prenatal closure of myelomeningocele: comparison of gelatin sponge and microsphere scaffolds and bioactive protein coatings. Tissue Eng Part A 17:1099-1110 